\title{
Haemorrhage of a cavernous haemangioma of the optic disc in pregnancy
}

\author{
José I Vela, Marta Garcia-Vilaró, José A Buil \\ Department of Ophthalmology, Hospital de Sant Pau, Barcelona, Spain \\ Correspondence to José I Vela, 34128jvs@comb.cat
}

\section{DESCRIPTION}

A healthy 29-year-old woman presented at 20 weeks' gestation with a 3-week history of a paracentral scotoma in her right eye. Visual acuity was 20/20 in both eyes. Fundus examination of the right eye showed a mass of numerous, grape-like, aneurysms filled with dark blood along the optic disc. White fibroglial tissue covered the surface. A triangular haemorrhage was observed in the macular area, under the internal limiting membrane, and stopping just at the border of the fovea (figure 1). Humphrey visual field testing showed an enlarged blind spot (figure 2). MRI revealed no additional abnormalities. The haemorrhage resolved favourably in 1 month (figures 3 and 4).

Cavernous haemangioma of the optic disc is an infrequent vascular haemartoma and it is almost always asymptomatic. ${ }^{12}$ Growth is rare although enlargement of the fibroglial component and fluctuations in the size of the lesion have been described. ${ }^{1}$ Bleeding is infrequent. Most

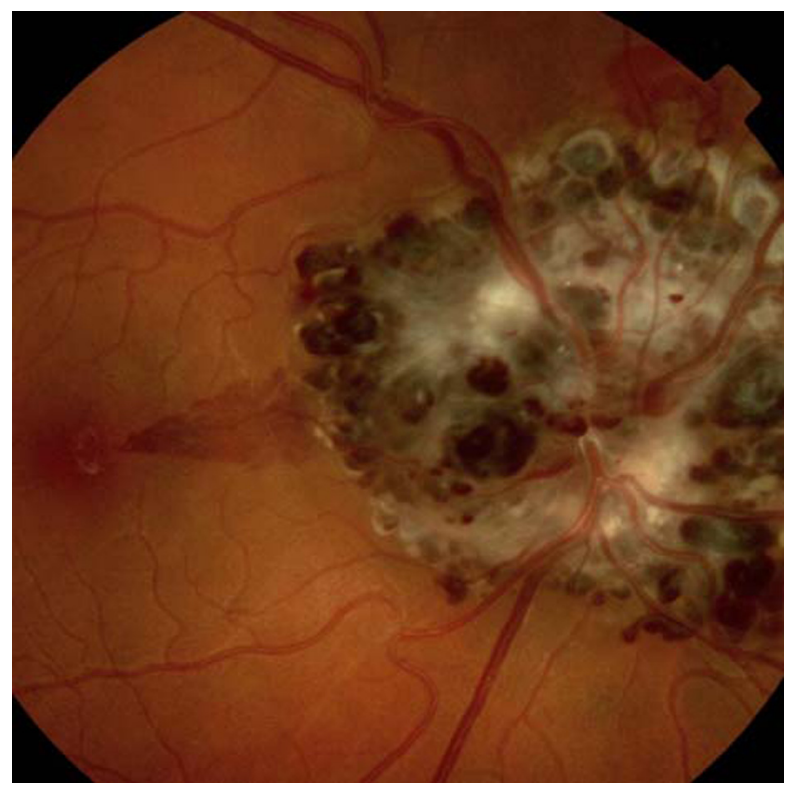

Figure 1 Fundus photograph of the right eye showing a mass of dark saccular aneurysms with overlying white fibroglial tissue. Note the triangular subinternal limiting membrane along the temporal margin of the lesion that stops near the fovea. Another subretinal haemorrhage can be seen in the upper margin. haemorrhages are minimal and not associated with longterm loss of visual acuity. ${ }^{1}$

We present a case of an extremely large cavernous haemangioma of the optic disc diagnosed during pregnancy following a subinternal limiting membrane haemorrhage in the macular region. Recently, Patikulsila et al reported a similar case in a 15 -year-old boy in whom the lesion remained stable without haemorrhages. ${ }^{2}$ Smith et al described a case of a retinal cavernous haemangioma that haemorrhaged during labour. They presumed that venous pressure elevation during Valsalva manoeuvre broke the wall of the aneurysms. ${ }^{3}$

It is unclear whether the haemorrhage was related to the pregnancy in our patient as no Valsalva stress was identified. Location of the haemorrhage was critical to diagnosing the tumour. The bleeding caused visual disturbance but loss of vision was not significant.

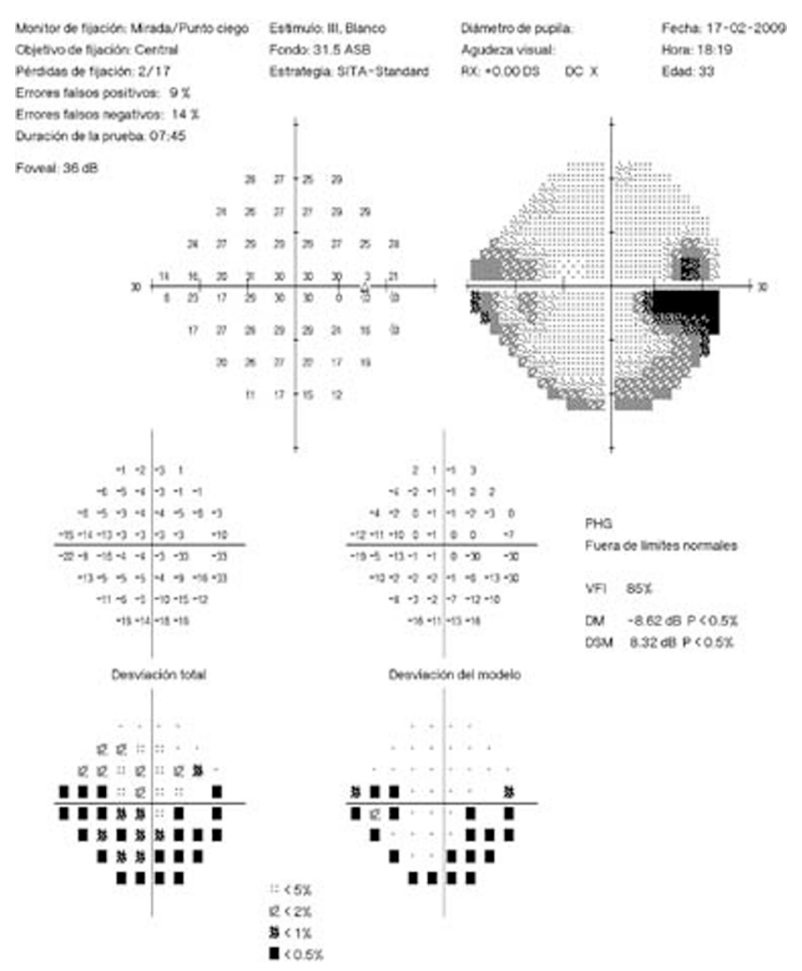

Figure 2 Humphrey visual field testing showing an enlarged blind spot. 


\section{BMJ Case Reports}

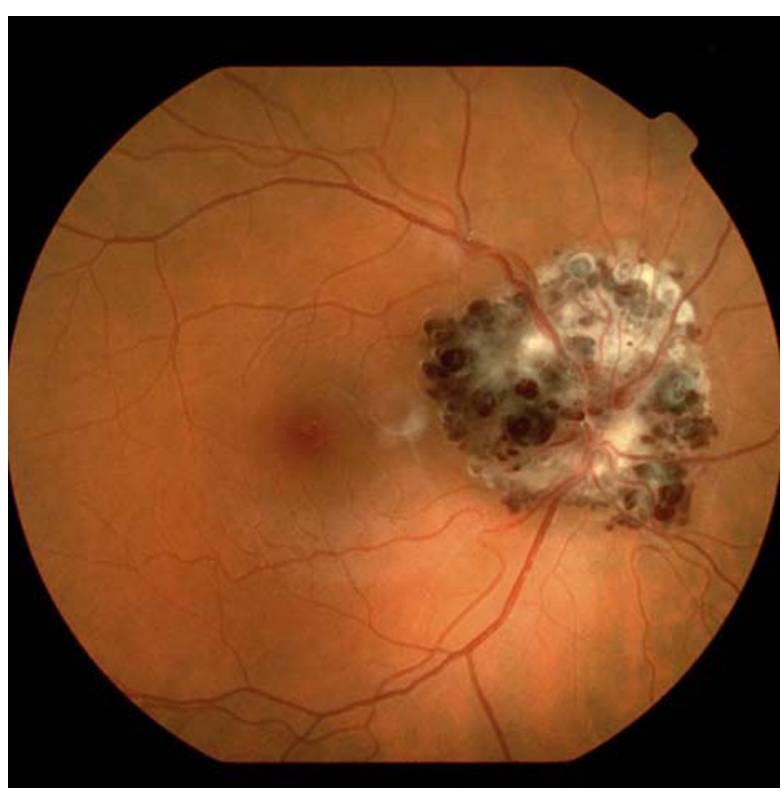

Figure 3 Clinical appearance showed resolution of the haemorrhage at 1 month.

Competing interests None.

Patient consent Obtained.

\section{REFERENCES}

1. Lewis RA, Cohen MH, Wise GN. Cavernous haemangioma of the retina and optic disc. Br J Ophthalmol 1975;59:422-4.

2. Patikulsila D, Visaetsilpanonta S, Sinclair SH, et al. Cavernous hemangioma

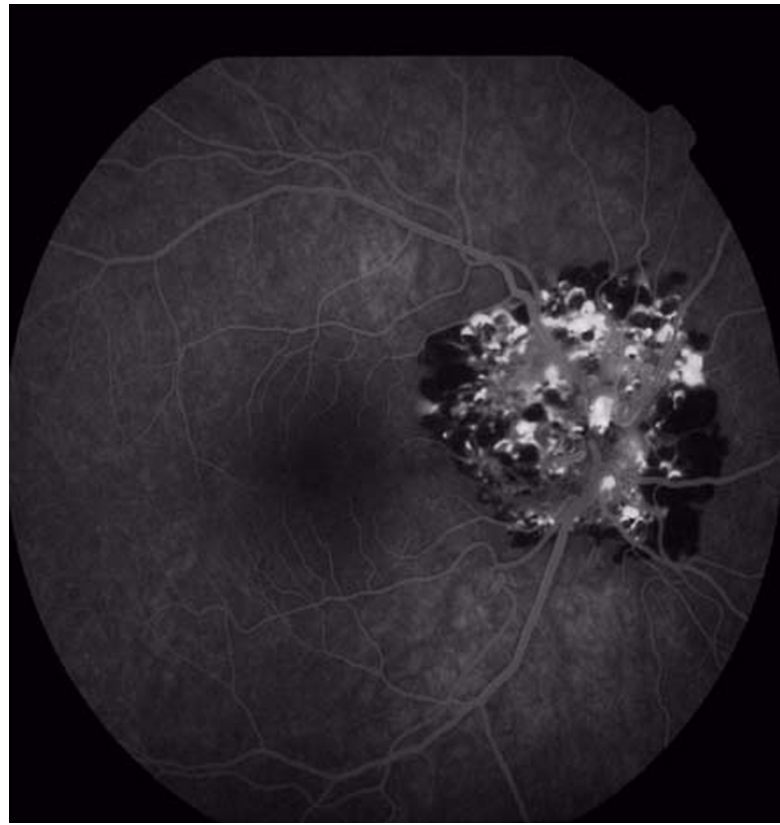

Figure 4 Late-frame of fluorescein angiogram demonstrated incomplete perfusion of the lesion and typical plasma-erythrocyte sedimentation.

of the optic disk. Retina 2007:27:391-2.

3. Smith BT, Joseph DP. Labor-induced hemorrhage of a retinal cavernous hemangioma of the optic disk. Ophthalmic Surg Lasers Imaging 2009;40:419-20.

This pdf has been created automatically from the final edited text and images.

Copyright 2010 BMJ Publishing Group. All rights reserved. For permission to reuse any of this content visit http://group.bmj.com/group/rights-licensing/permissions.

BMJ Case Report Fellows may re-use this article for personal use and teaching without any further permission.

Please cite this article as follows (you will need to access the article online to obtain the date of publication).

Vela JI, Garcia-Vilaró M, Buil JA. Haemorrhage of a cavernous haemangioma of the optic disc in pregnancy. BMJ Case Reports 2010;10.1136/bcr.03.2010.2806, date of publication

Become a Fellow of BMJ Case Reports today and you can:

- Submit as many cases as you like

- Enjoy fast sympathetic peer review and rapid publication of accepted articles

Access all the published articles

- Re-use any of the published material for personal use and teaching without further permission

For information on Institutional Fellowships contact consortiasales@bmjgroup.com

Visit casereports.bmj.com for more articles like this and to become a Fellow 